\title{
Correlation of Physical and Genetic Maps of Human Chromosome 16
}

Annual Progress Report

for period October 11990 to July 311991

Grant R. Sutherland

\begin{abstract}
Adelaide Children's Hospital
North Adelaide SA 5006

Australia
\end{abstract}

\author{
Prepared for \\ THE U.S. DEPARTMENT OF ENERGY \\ AGREEMENT Nก. DE-FG02-89ER60863, A003
}

NOTICE

This report was prepared as an account of work sponsored by the United States Government. Neither the United States nor the Department of Energy, nor any of their employees, nor any of their contractors, subcontractors, or their employees, makes any' warranty, express or implied, or assumes any legal liability or responsibility for the accuracy, completeness, or usefulness of any information, apparatus, product or process disclosed or represents that its use would not infringe privately-owned rights. 


\section{ANNUAL PROGRESS REPORT}

TITLE : CORRELATION OF PHYSICAL AND GENETIC MAPS OF HUMAN CHROMOSOME 16.

PRINCIPAL INVESTIGATOR : G.R. Sutherland

SENIOR ASSOCTATES : D.F. Callen, J.C. Mulley, R.I. Richards

\section{ABSTRACT}

This project aimed to divide chromosome 16 into approximately 50 intervals of $-2 M b$ in size by constructing a serieg of mouse/human somatic cell hybrids each containing a rearranged chromosome 16 . Using these hybrids, DNA probes would be regionally mapped by southern blot or PCR analysis. Preference would be given to mapping probes which demonstrated polymorphisms for which the CEPH panel of families had been typed. This would allow a correlation of the physical and linkage maps of this chromosome.

The aims have been substantially achieved. 49 somatic cell hybrids have been constructed which have allowed definition of 46 , and potentially 57 , different physical intervals on the chromosome. 164 loci have been fully mapped into these intervals. A correlation of the physical and genetic maps of the chromosome is in an advanced stage of preparation. The somatic cell hybrids constructed have been widely distributed tu groups working on chromosome 16 and other genome projects.

\section{REPORT}

The principal objectives of this project were to create a somatic cell hybrid panel which could divide chromosome 16 into 50 intervals, each of 
average size 2 megabases. To delineate these intervals a large number of anonymous DNA probes and gene probes would be mapped. These mapped probes were to include those genetically mapped in the CEPH pedigrees and thus allow a detailed correlation of the physical and linkage maps of chromosome 16.

The principal aim of this project has now been achieved. A total of 49 mouse/human somatic hybrids each containing different portions of chromosome 16 have been isolated and characterised. The breakpoints represented in these 49 hybrids, together with the four fragile sites on this chromosome, define a minimum of 46 and potentially 57 different physical intervals of chromosome 16. Since chromosome 16 is estimated to be $100 \mathrm{Mb}$ in length this therefore corresponds to a physical map of less than $2 \mathrm{Mb}$ average resolution. A total of 164 loci have been mapped to this panel as shown in the Figure 1 (a further 43 have been mapped, but not in detail, and are omitted from the figure). Not all potential intervals defined by hybrid breakpoints and fragile sites have been differentiated since there are intervals which do not contain any mapped loci. This hybrid panel is now the basis for all physical mapping on chromosome 16 .

The mapped loci are genes, polymorphic probes, cosmids from the Los Alamos contigs (Stallings et al, 1990) and anonymous DNA probes generated in our laboratory and elsewhere (Figure 1). An increasing emphasis has been placed on the use of PCR. STSs representing genes, $(A C)$ n repeats and anonymous sequences have been generated and mapped.

Probes which are polymorphic, in particular those from Collaborative Research Incorporated and $C$. Julier have been physically mapped to this chromosome. Detailed linkage maps in the regions of chromosome 16 near the fragile sites FRA16A and FRA16B have been completed. A correlated physical and genetic map for this entire chromosome is being constructed and has 
already been constructed around the gene for Batten disease (Callen et al, 1991). In some regions of chromosome 16 (AC) n repeats have been isolated and typed in the CEPH pedigrees to improve the resolution of this linkage map.

A comprehensive collaboration is in progress with the chromosome 16 group at the Los Alamos National Laboratory. This involves ongoing exchange of materials and data. Collaborative projects include the physical mapping of cosmids from contigs to evaluate the integrity and random distribution of contigs and the investigation of "problem" contigs where branching occurs or contigs are abnormally large.

Hybrids and DNA probes generated from this project have been distributed to a number of laboratories and ongoing collaborative effortg are in progress to map and to clone particular regions of interest. These include:

1. Dr. Reeders (Yale, USA) : cloning polycystic kidney disease.

2. Dr. M. Gardiner (Oxford, England) : mapping and cloning Batten disease.

3. Prof. W. Van de Ven (Leuven, Belgium) : cloning breakpoint of human myxoid liposarcoma.

4. Dr. Cheryl Willman (Albequerque, USA) : mapping and cloning leukemia breakpoints on chromosome 16 .

5. Dr. M.H. Breuning (Leiden, Netherlands) : cloning the $t(8 ; 16)$ chromosome breakpoints in leukemia.

6. Dr. A. Reeve (Dunedin, New zealand) : Identifying regions involved in Wilms tumour.

7. Dr. H. Tsuda (Tokyo, Japan) : identifying regions involved in hepatocellular carcinoma.

8. Dr. J.L. Weber (Marshfield, USA) : mapping (AC)n repeats. 
PUBLICATIONS ARISING FROM THIS GRANT :

Callen, D.F., E. Baker, S.Lane. (1990). Re-evaluation of GM2346 from a $\operatorname{del}(16)(q 22)$ to $t(4 ; 16)(q 35 ; q 22.1)$. Clin. Genet. 38: 466-468.

Callen, D.F., E. Baker, H.J. Eyre, S.A. Lane. (1990) An expanded mouse-human hybrid cell panel for mapping human chromosome 16 . Ann. Genet. 33: 190-195.

Callen, D.F., E. Baker, H.J. Eyre, J.E. Chernos, J.A. Bell, G.R. Sutherland. (1990) Reassessment of two apparent deletions of chromosome $16 \mathrm{p}$ to an ins $(11 ; 16)$ and a $t(1 ; 16)$ by chromosome painting. Ann. Genet. 33: 219-221.

Callen DF, Baker $E$, Lane $S$, Nancarrow $J$, Thompson A, Whitmore SA, Holman K, Richarda RI, Maclennan DH, Berger R, Cherif D, Jarvela I, Peltonen L, Sutherland GR and Gardiner RM. (1991) Regional mapping of the Batten disease locus (CLN3) to human chromosome $16 \mathrm{pl}$ (Am. J. Hum. Genet. (In press).

Chen, L.z., P.C. Harris, S. Apostolou, E. Baker, K. Holman, S.A. Lane, J.K. Nancarrow, S.A. Whitmore, R.L. Stallings, C.E. Hildebrand, R.I. Richards, G.R. Sutherland, D.F. Callen. A refined physical map of the long arm of chromosome 16. Genomica 10: 308-312.

Dixon, M.J., E. Haan, E. Baker, D. David, N. Mckenzie, R. Williamson, J. Mulley, M. Farrall, D. Callen. (1991) Association of Treacher Collins syndrome and translocation 6p21.31/16p13.11: Exclusion of the locus from these candidate regions. Am. J. Hum. Genet. 48: 274-280.

Hyland, V.J., K.E.W. Fernandez, D.F. Callen, R.N. Mackinnon, E. Baker, K. Friend, G.R. Sutherland. (1989) Assignment of anonymous DNA probes to specific intervals of human chromosome 16 and $X$. Hum. Genet. 83: 61-66.

Hyland, V.J., G.K. Suthers, K. Friend, R. Mackinnon, D.F. Callen, M.H. Breuning, T. Keith, V.A. Brown, P. Phippg, G.R. Sutherland. (1990) Probe VK5B, is located in the same interval as the autosomal dominant adult polycystic kidney disease locus, PKDI. Hum. Genet. $84: 286-288$.

Kozman HM, Gedeon AK, Whitmore S, suthers GK, Callen DF, Sutherland GR, Mulley JC. (1991) Addition of MT, D16S10, D16S4 and D16S91 to the linkage map within 16q12.1-q22.1. Genomics (In press).

Mulley, J.C., N. Barton, D.F. Callen. (1990) Localigation of human $\underline{\text { PGP }}$ and HAGH genes to 16p13.3 Cytogenetic. Cell Genet. 53: 175-176.

Pritchard, M.A., Baker, E., Whitmore, S.A., Sutherland, G.R., Idzerda, R.L., Park, L.S., Cosman, D., Jenkins, N.A., Gilbert, D.J., Copeland, N.G., Beckmann, M.P. (1991) The interleukin-4 receptor gene (IL4R) maps to 16p11.2-16p12.1 in human and to the distal region of mouse chromosome 7. Genomics 10: 801-806. 
Richards, R.I., K. Holman, S. Lane, G.R. Sutherland, D.F. Callen. (1991) Human Chromosome 16 physical Map : mapping of somatic cell hybrids using multiplex PCR deletion analysis of sequence tagged sites. Genomics (In Press).

Sutherland, G.R., E. Baker, D.F. Callen, O.M. Garson, A.K. West. (1990) The human metallothionein gene cluster is not disrupted in myelomonocytic leukemia. Genomics 6: 144-148.

cprorep 
Fig. 1 Physical map of human chromosome 16.

On the left of the ideogram are hybrid breakpoints, generally represented by a " $C Y$ " suffix. Also represented are the four fragile sites, FRA16A, FRA16B, FRA16D and FRA16E. The positions of the breakpoints are represented by horizontal lines.

On the right of the ideogram are the probes which have been physically mapped by a variety of techniques including probing of Southern blots, PCR and in situ hybridization. The "D" numbers have been abbreviated e.g. from D16S85 to S85. Probe names are given in brackets. Those probes which are not colour coded are various anonymous DNA probes. The colour coding of the probes is as follows:

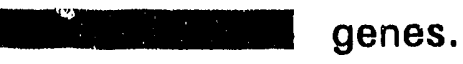

genes which are STSs.

cosmids from Los Alamos Nat. Lab. which are members of contigs.

probes which have been typed in the $\mathrm{CEPH}$ pedigrees.

STSs which are $(A C)$ n repeats. 


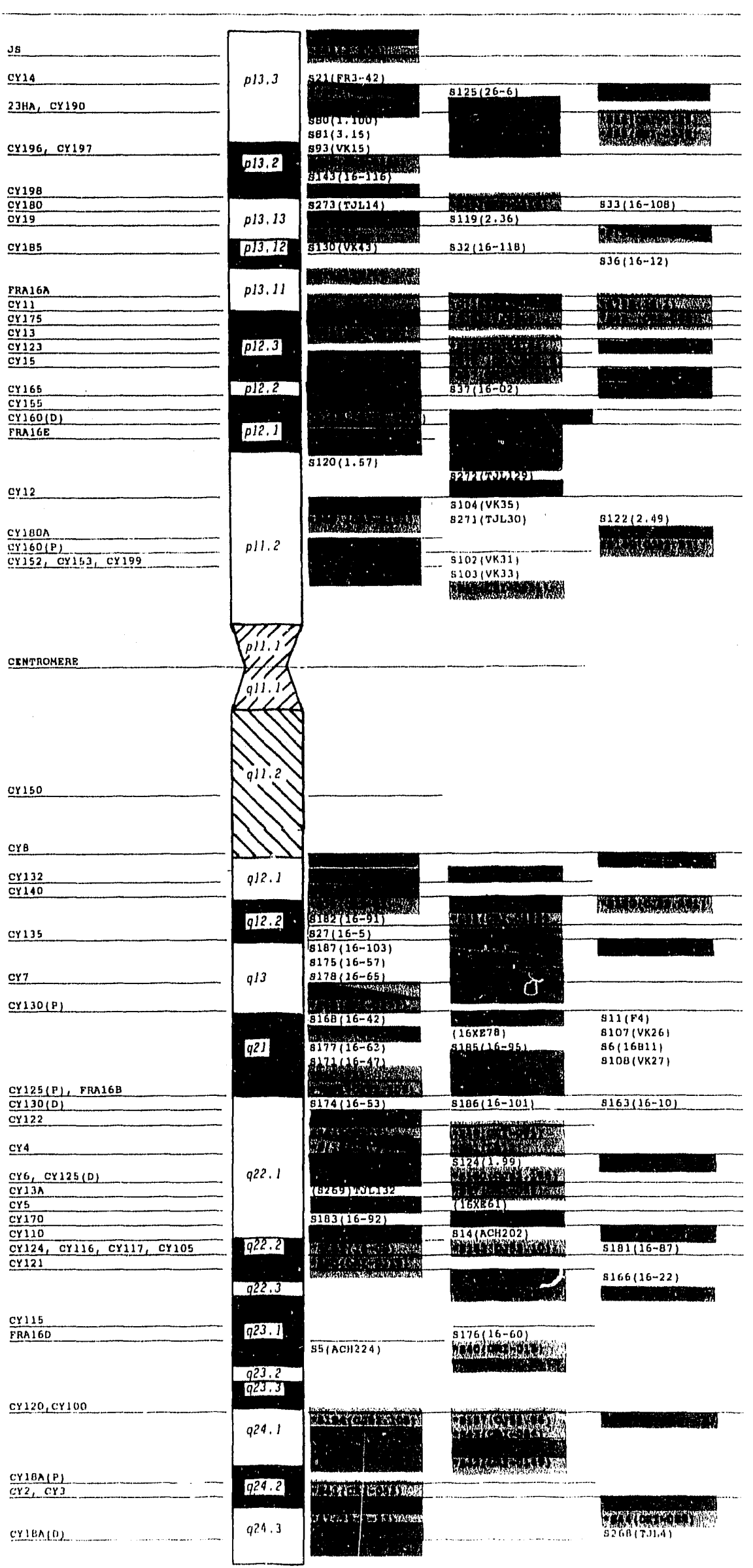



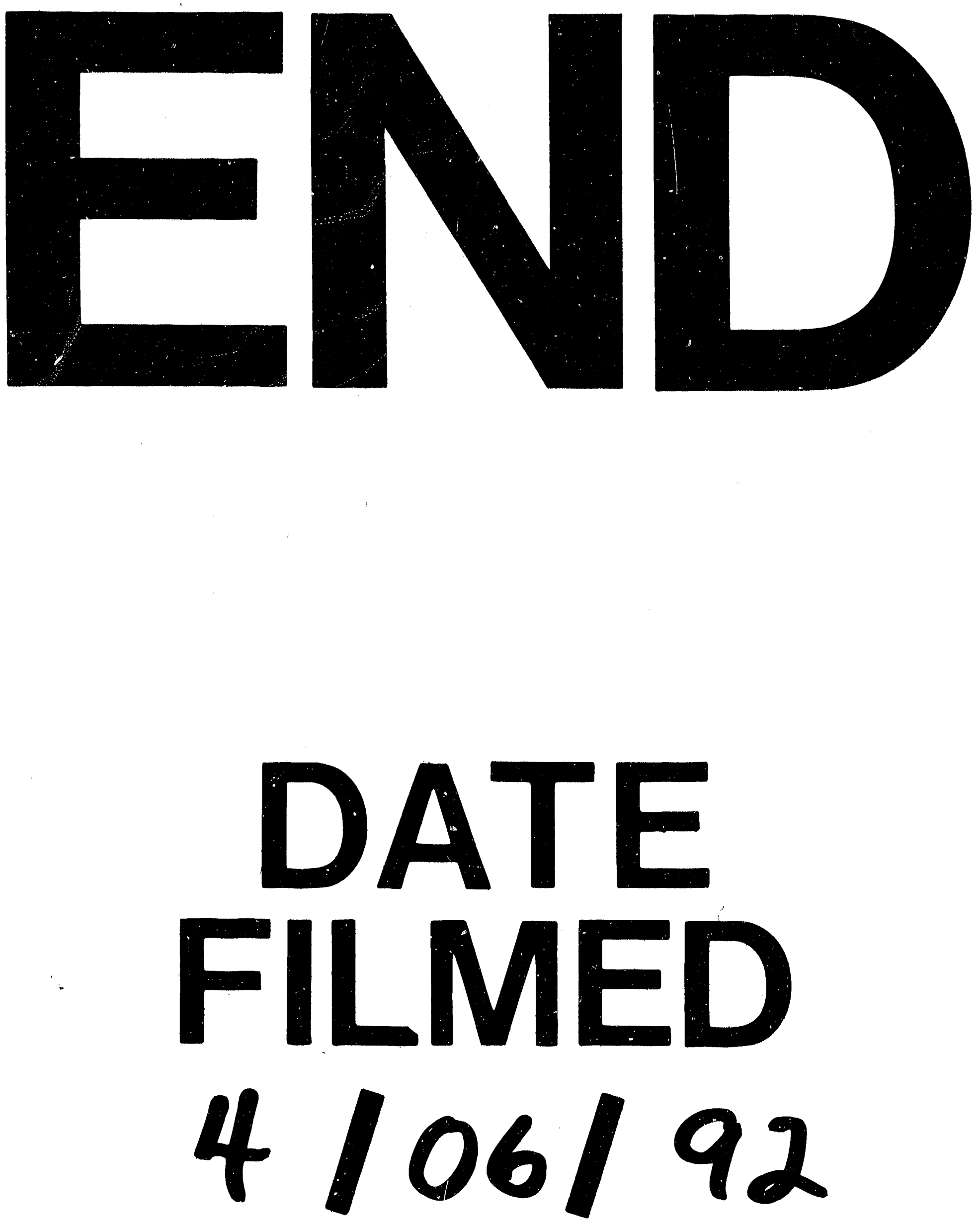

1 
